\title{
PENINGKATAN KETERAMPILAN BERBICARA MENGGUNAKAN TEKNIK BERCERITA DAN BERPIDATO PADA MAHASISWA PROGRAM STUDI PENDIDIKAN BAHASA INDONESIA FKIP UNIVERSITAS BENGKULU
}

\author{
Agus Joko Purwadi ${ }^{1}$, Didi Yulistio ${ }^{2}$ \\ ${ }^{1,2}$ Program Studi Pendidikan Bahasa Indonesia, FKIP, Universitas Bengkulu \\ Jalan W.R. Supratman, Kandang Limun, Kota Bengkulu, Indonesia \\ Email: agusjokop2808@unib.ac.id ${ }^{1}$, yulistiodidi@unib.ac.id ${ }^{2}$
}

\begin{abstract}
Abstrak
Tujuan penelitian ini untuk mendeskripsikan peningkatan keterampilan berbicara menggunakan teknik bercerita dan berpidato mahasiswa Program Studi S-1 Pendidikan Bahasa dan Sastra Indonesia FKIP Universitas Bengkulu. Metode penelitian menggunakan metode penelitian tindakan kelas dengan model Hopkins yang dilaksanakan dalam dua siklus. Setiap siklus dilaksankan melalui empat tahapan mencakup tahap perencanaan, tahap tindakan, tahap pengamatan, dan tahap refleksi. Sumber data penelitian ini adalah mahasiswa Prodi S-1 Pendidikan Bahasa dan Sastra Indonesia FKIP Universitas Bengkulu, semester II kelas A sebanyak 34 orang. Data penelitian ini berupa penampilan mahasiswa dalam berpidato dan bercerita. Teknik pengumpulan data berupa tes berbicara, yakni berpidato dan bercerita. Analisis data menggunakan rumus rerata dan analisis akhir secara kualitatif. Hasil penelitian menunjukkan bahwa terjadi peningkatan keterampilan berbicara menggunakan teknik bercerita dan berpidato pada mahasiswa. Hal ini dapat dilihat dari proses dan hasil pembelajaran pada siklus I dengan rerata skor sebesar 71,88 kategori baik, meningkat pada siklus II dengan skor sebesar 81,18 kategori sangat baik. Secara khusus kenaikan ini terjadi pada keterampilan bercerita dengan skor 72,9 berkategori baik, dan berpidato dengan skor 70,85 kategori baik meningkat pada siklus II untuk keterampilan bercerita dengan skor 80,7 berkategori sangat baik dan berpidato dengan skor 81,65 berkategori sangat baik. Peningkatan keterampilan berbicara ini diikuti dengan meningkatnya aktivitas mahasiswa dalam proses pembelajaran pada siklus I dengan sikap aktif meningkat pada siklus II menjadi sangat aktif dalam sikap integritas, kemandirian, disiplin, tanggung jawab, dan kejujuran.
\end{abstract}

Kata kunci: keterampilan, berbicara, teknik bercerita, teknik berpidato

\section{IMPROVING SPEAKING SKILLS USING STORYTELLING AND SPEECH TECHNIQUES FOR STUDENTS OF THE INDONESIAN LANGUAGE EDUCATION STUDY PROGRAM, FKIP BENGKULU UNIVERSITY}

\begin{abstract}
The purpose of this study was to describe the improvement of speaking skills using storytelling techniques and making speeches by students of the Indonesian Language and Literature Study Program, FKIP University of Bengkulu. The research method used is a classroom action research method with the Hopkins model which was implemented in two cycles. Each cycle is carried out through four stages including the planning stage, the action stage, the observation
\end{abstract}


stage, and the reflection stage. The data sources of this research were 34 students of the S-1 Indonesian Language and Literature Education Study Program, Bengkulu University, semester II class A. The data of this research are in the form of students' performances in making speeches and telling stories. The data collection technique is in the form of a speaking test, namely making speeches and telling stories. The data analysis used the mean formula and the final analysis was qualitative. The results showed that there was an increase in speaking skills using storytelling techniques and speaking to students. This can be seen from the process and learning outcomes in the first cycle with an average score of 71.88 in the good category, increasing in the second cycle with a score of 81.18 for the very good category. In particular, this increase occurred in storytelling skills with a score of 72.9 in the good category, and speech with a score of 70.85 in the good category, increased in cycle II for storytelling skills with a score of 80.7 in the very good category and speaking with a score of 81.65 in the very good category.

. This improvement in speaking skills was followed by an increase in student activity in the learning process in cycle I with an increasing active attitude in cycle II being very active in an attitude of integrity, independence, discipline, responsibility, and honesty.

Keywords: skills, speaking, storytelling techniques, speech techniques

\section{A. Pendahuluan}

Keterampilan berbicara merupakan keterampilan berbahasa lisan yang bersifat produktif disamping keterampilan berbahasa tulis yakni keterampilan menulis yang harus dikuasai mahasiswa calon pendidik bahasa Indonesia (Jazeri, 2016:218). Hal ini dikarenakan mahasiswa calon guru bahasa Indonesia dalam aktivitasnya harus terampil berbahasa Indonesia, termasuk menguasai bidang keterampilan berbahasa, pengajaran bahasa, kebahasaan, dan kesastraan. Penguasaan materi itu dalam profesional pendidik termasuk kompetensi profesional atau akademik (Haswindy, 2020:203). Disamping itu, mahasiswa calon guru bahasa Indonesia harus mengerti hal apa yang akan diajarkan dan cara mengajarkannya atau disebut ilmu mengajar atau kompetensi pedagogik. Cooper (dalam Satori, 2013) menegaskan bahwa kemampuan dasar profesi guru ini, paling tidak mencakup empat komponen, yakni (1) memiliki keterampilan praktik belajar dan mengajar (teaching and learning), (2) memiliki keterampilan materi bidang keilmuan yang diampu, (3) memiliki keterampilan sikap hubungan sosial dengan masyarakat pendidikan secara baik, dan (4) memiliki perilaku dan kepribadian terhadap diri sendiri, teman sejawat, dan orang lain di tempatnya bereksistensi yang juga baik.

Keterampilan berbicara merupakan keterampilan berbahasa Indonesia yang paling awal harus dikuasai oleh setiap pembelajar (mahasiswa) ini sangat 
penting karena sebagai wujud nyata dari seseorang dalam berpendapat dan mengeluarkan gagasan atu ide-ide secara lisan sehingga bisa mempersuasi pendengar (Noermanzah, 2018:119-120). Sebab, keterampilan seorang mahasiswa dalam berbicara secara baik akan menunjukkan keruntutan pola berpikirnya yang juga baik. Keterampilan berbicara ini perlu secara terus-menurus dilatih untuk mencapainya. Kegiatan melatih diri dalam berbicara ini dapat dilakukan melalui berbagai bidang kegiatan seperti melalui wawancara, berdiskusi, bercerita, berpidato, dan bercakap-cakap yang terarah serta lainnya. Pemilikan keterampilan berbicara di muka umum sangat penting bagi mahasiswa calon guru bahasa Indonesia. Sebab, keterampilan ini berguna ketika melakukan perkuliahan untuk menyampaikan pertanyaan atau pendapat dan ketika sudah terjun menjadi pendidik di kelas yang menjadi tanggung jawabnya. Kenyataan di lapangan saat ini masih banyak mahasiswa Program Studi Pendidikan Bahasa Indonesia yang belum memiliki keterampilan ini. Padahal Mata Kuliah Keterampilan Berbicara sudah diajarkan pada semester dua (semester genap) tahun kuliah. Dengan menitikberatkan pada kajian penguasaan faktor kebahasaan dan faktor nonkebahasaan dalam praktiknya.

Perbaikan dan penanaman terhadap beberapa faktor ini akan cepat dicapai apabila mahasiswa melakukan keterampilan berbicara melalui beberapa bidang di atas. Di antara beberapa bidang keterampilan berbicara yang berperan penting dan perlu diupayakan dalam perkuliahan, yakni keterampilan berpidato dan keterampilan bercerita. Hal ini penting dilakukan karena kedua keterampilan ini melibatkan secara individual penguasaan unsur kebahasaan dan nonkebahasaan. Dari sisi kebahasaan meliputi proses berpikir, bernalar secara runtut, dan penguasaan gagasan, ide pokok, serta isi cerita. Disamping ketepatan lafal dan intonasi serta kemampuan dalam memilih kata dan gaya bahasa dalam bercerita atau berpidato. Dari sisi unsur nonkebahasaan kedua bidang keterampilan berbicara tersebut melibatkan secara penuh keberanian untuk tampil di muka umum, ketepatan dalam mimik dan pandangan mata, kepercayaan diri yang tinggi, dan penghayatan isi pesan yang disampaikan. Hisam (2016) menegaskan 
bahwa dalam keterampilan berbicara seperti bercerita diperlukan kesiapan seseorang dalam pikiran, kesiapan mental, keberanian, kejelasan lafal dan intonasi sehingga isi cerita (pesan) yang disampaikan dapat dengan mudah dipahami orang lain.

Berkaitan dengan tingkat literasi (tingkat berpikir) dalam berbicara-bacatulis siswa kita secara nasional, pada pencapaian level PISA bahasa tahun 2012 dengan rata-rata hanya berada pada level 3 berkategori cukup sementara negara lain di Asia Tenggara sudah di atasnya (OECD, 2014). Disamping itu, hasil studi organisasi Internasional, seperti TIMMS, bahwa sebagian besar siswa Indonesia hanya mampu menjawab persoalan pada level menengah (sebanyak 95\%) sedangkan kemampuan siswa dalam menjawab soal yang memerlukan pemikiran masih sangat rendah (hanya 5\%) (Kemdikbud, 2013:2). Oleh karena itu, tingkat literasi (berpikir kritis dan cepat) anak harus dilakukan pembinaan sebagai upaya menumbuhkan kompetensi dan performansi melalui budaya berbicara dan menulis, khususnya mengembangkan hal-hal apa yang dilihat, didengar, dan dipikirkan sehingga memungkinkan memunculkan ide-ide kritis-kreatif yang dapat dikembangkan ke dalam bentuk proses berpikir yang lebih tinggi.

Kualitas literasi (berpikir) siswa yang rendah tidak dapat dipungkiri itu sebagai dampak dari pola pembelajaran bahasa Indonesia yang dipilih guru. Untuk itu, pengembangan kemahiran berbahasa Indonesia lisan melalui keterampilan berbicara perlu dilakukan. Pengembangan keterampilan berbicara merupakan salah satu upaya membina dan mengembangkan pola berpikir peserta didik secara cepat, runtut, kritis, dan kreatif. Keterampilan berbicara berbasis praktik bercerita dan berpidato ini harus dimiliki oleh mahasiswa calon guru bidang studi Pendidikan bahasa Indonesia sebagai model pembelajaran berkomunikasi. Pencapaian kompetensi literasi sesuai kurikulum 2013 sudah dicanangkan sejak sekolah dasar. Pada tingkat ini, siswa telah dituntut untuk menyimak, membaca, berdiskusi, memberi komentar, dan menulis kalimat dengan gagasan sederhana dalam urutan yang jelas dan menggunakan kata-kata sendiri. Selain itu, sesuai standar kompetensi lulusan bidang studi bahasa Indonesia, bahwa orientasi literasi berkenaan dengan keterampilan membaca dasar, perpustakan, media, dan 
pemanfaatan teknologi informasi komunikasi, dan menulis dalam berbagai konteks dengan tujuan untuk mencapai pembelajaran komunikatif (Bachman, 1990:85). Kemampuan dan kecakapan keterampilan literasi pembelajar akan berdampak pada keterampilan berbicara dan menulis sebagai wujud pencapaian dari keterampilan yang bersifat produktif dan berpikir tingkat tinggi.

Dalam pembelajaran keterampilan berbicara perlu pencapaian kompetensi unsur kebahasaan dan nonkebahasaan yang memadai dan serta kepekaan kontekstual yang tinggi. Sebab, berbicara yang sederhana sekalipun tidak mungkin dapat tercapai tanpa menyertakan pengetahuan kaidah kebahasaaan yang juga sederhana dan pemilikan unsur nonkebahasaan yang sudah dilatihkan. Namun, kenyataan menunjukkan, hasil pembelajaran keterampilan berbicara masih jauh dari harapan. Masih banyak mahasiswa yang kurang mampu menguasai topik dalam berbicara secara cepat karena belum memiliki pengalaman kegiatan formal yang memadai dan teknik berbicara yang secara psikologis belum memperhatikan aspek logika berpikir yang sesuai etika, estetika, dan kesantunan dalam berbicara secara baik. Oleh karena itu, perlu ada upaya secara terus-menerus untuk melatih keterampilan berbicara baik melalui bercerita, berpidato, berdiskusi, dan lainnya di luar perkuliahan keterampilan Berbicara.

Haryadi dan Zamzami (1996) berbicara merupakan suatu proses mengekspresikan, menyatakan, dan menyampaikan gagasan, pikiran dan isi hati kepada orang lain dengan menggunakan bahasa lisan yang dapat dimengertian dan bermakna bagi orang lain. Sejalan dengan pendapat di atas Tarigan dkk. (1983) menjelaskan berbicara sebagai suatu aktivitas mengucapkan bunyi-bunyi artikulasi atau kata-kata untuk mengekspresikan, menyatakan dan menyampaikan pikiran, gagasan, dan perasaan. Oleh karena itu, berbicara merupakan bentuk perilaku manusia yang memanfaatkan berbagai faktor. seperti faktor fisik, psikologis, neurologis, semantik, dan linguistik. Kaitannya dengan keterampilan, bahwa keterampilan berbicara merupakan suatu kecakapan atau kemampuan hasil usaha seseorang dalam proses menuangkan buah pikiran melalui komunikasi dalam bahasa lisan dengan menggunakan kata-kata, kalimat-kalimat 
yang dirangkai secara lengkap, dan jelas sehingga dapat dipahami orang lain secara berhasil. Hal ini sebagaimana Rivers (dalam Hadley, 1993:290-292) mengemukakan bahwa kemampuan berbicara merupakan kecakapan seseorang dalam praktik berbahasa lisan secara alamiah dengan memanfaatkan konteks nyata.

Keterampilan berbicara yang diwujudkan melalui teknik keterampilan bercerita dan berpidato sangat berperan penting. Bercerita merupakan salah satu bentuk tugas keterampilan berbicara yang bertujuan untuk mengungkapkan kemampuan yang bersifat pragmatis lisan dari seseorang (Nurgiyantoro, 2001:278). Tarigan (1981:35) menyatakan bahwa bercerita merupakan salah satu keterampilan berbicara yang dimaksudkan untuk memberikan informasi kepada orang lain karena termasuk dalam situasi informatif untuk memberikan pengertian dan makna yang jelas. bercerita merupakan kemampuan mengucapkan bunyi artikulasi berupa kata-kata untuk mengekspresikan, mengatakan, dan menyampaikan pikiran, gagasan, dan perasaan yang memanfaatkan faktor fisik, psikologis, neurologist, dan linguistik secara luas. Dengan kata lain bahwa bercerita yang juga dikenal dengan 'mendongeng', yakni kegiatan menuturkan atau mengisahkan suatu kejadian kebahagiaan atau penderitaan yang dialami seseorang baik kejadian sesungguhnya atau rekaan yang disampaikan secara lisan menggunakan bahasa yang khas dengan penghayatan sehingga memberikan pengalaman menarik dan berkesan yang bermanfaat bagi orang lain. Di sisi lain, Tarigan (1981:35) mendeskripsikan bahwa berpidato adalah suatu kegiatan bertutur atau berbahasa lisan yang disusun dalam struktur formal dan sistematis untuk menyampaikan informasi, pendapat, dan stimulus sesuai topik yang ditetapkan secara baik atau digunakan untuk memberikan respon terhadap pendapat/opini umum kepada orang lain. Keterampilan berpidato yang baik di depan umum dapat membantu orang lain untuk mendapatkan informasi secara lisan.

Tompkins dan Hoskisson (dalam Rofi'udin dan Zuhdi, 2001:8) mengemukakan proses pengembangan pembelajaran berbicara dapat dilakukan melalui kegiatan: (1) percakapan, (2) berbicara estetik, seperti bercerita, (3) 
berbicara untuk menyampaikan informasi secara lisan, berpidato, wawancara dan debat, dan (4) kegiatan dramatik, berkaitan dengan melatih dan mencoba menafsirkan sendiri naskah. Tarigan (2008) mendeskripsikan langkah-langkah berpidato meliputi (a) menentukan topik dan penguasaan isi, (b) membuat struktur kerangka pidato mencakup pendahuluan, isi, dan penutup, (c) penampilan memperhatikan kepercayaan diri dan kesiapan psikis, kesiapan fisik; cara berpakaian dan lingkungan tempat berbicara atau berpidato, dan (d) kemampuan mengembangkan wawasan dalam berbicara. Mudini dan Purba (2009) mendeskripsikan karakteristik pembelajaran bercerita meliputi (1) adanya pelibatan pendengar, (2) penguasaan lafal, struktur, dan kosa kata, (3) ada tema/topik yang diceritakan, (4) ada informasi yang ingin disampaikan atau sebaliknya ditanyakan, (5) memperhatikan situasi dan konteks.

Untuk menilai dua keterampilan berbicara yang mendasarkan pada teknik bercerita dan berpidato dapat digunakan rubrik penilaian dengan memperhatikan unsur kualitas, menurut Nurgiyantoro (2001:410) dan Djiwandono (2008) meliputi (1) ketepatan isi cerita, (2) ketepatan penunjukkan detail cerita, (3) ketepatan logika cerita, (4) ketepatan makna seluruh cerita, (5) ketepatan pilihan kata, dan (6) ketepatan kalimat serta (7) kelancaran dalam bercerita. Berdasarkan deskripsi rubrik penilaian tersebut dapat dikemukakan rubrik penilaian keterampilan berbicara dengan menggunakan teknik bercerita dan berpidato dalam penelitian ini dengan total skor maksimal 100, mencakup (1) kesesuaian tema dengan isi (skor 10), (2) ketepatan struktur teks tulis cerita dan pidato (skor 10), (3) ketepatan lafal, intonasi suara, dan jeda ( skor 10), (4) ketepatan diksi, kalimat, dan paragraf (skor 15), (5) kesesuaian gaya bahasa pengucapan dalam bercerita dan berpidato (skor 10), (6) kelancaran dalam bercerita dan berpidato (skor 10), (7) kepercayaan diri dan keberanian (skor 10), (8) kesesuaian pengembangan wawasan dalam berbicara (skor 10), dan (9) penampilan; mimik, pandangan mata, gerak-gerik tubuh, dan cara berpakaian (skor 15).

Hasil pengamatan peneliti dalam perkuliahan Program Studi Pendidikan Bahasa dan Sastra Indonesia FKIP Universitas Bengkulu di setiap angkatan yang 
berbeda, menunjukkan masih banyak mahasiswa yang sulit ketika akan mengemukakan pendapat, menyampaikan ide atau gagasan tentang sesuatu dan bertanya dengan menggunakan kalimat bahasa Indonesia yang runtut dan efektif serta santun. Bahkan faktor kebahasaan ini masih belum ditunjang dengan faktor nonkebahasaan yang juga kurang mendukung, seperti kurang keberaniannya untuk berbicara di depan teman-temannya di kelas, tidak percaya diri (self confidance), bahkan tidak menguasai pokok pembicaraan, dan masih lemahnya faktor kebahasaan lain, seperti ketepatan lafal yang masih terbawa unsur kedaerahan serta pilihan kata. Padahal perkuliahan keterampilan berbicara sudah dilatihkan pada faktor-faktor dasar tersebut.

Disamping itu, hasil pengamatan penulis terhadap tugas-tugas yang dibuat mahasiswa Prodi Pendidikan Bahasa Indonesia FKIP Universitas Bengkulu yang berkaitan dengan tugas praktik dalam bentuk keterampilan berbicara belum memperhatikan formalitas aspek pengukuran tiap-tiap aspek keterampilan tersebut. Artinya, produk kemampuan berbicara sudah harus dinilai sesuai rubrik penilaian masing-masing aspek. Kemampuan menilai ini mestinya sudah dimiliki oleh setiap mahasiswa calon guru. Oleh karena itu, penelitian ini juga dimaksudkan untuk membekali mahasiswa dalam hal mempraktikkan setiap aspek keterampilan berbicara seperti bercerita, berpidato dan cara menilainya sehingga mereka benar-benar memiliki kecakapan dalam mempraktikkannya.

Bukti pemilikan kemahiran mahasiswa calon guru bahasa lindonesia dalam pembelajaran keterampilan berbicara yang diwujudkan melalui teknik bercerita dan berpidato akan berdampak pada pencapaian keterampilan berbahasa Indonesia secara baik, khususnya dalam mencapai standar kompetensi lulusan. Oleh karena itu, peningkatan keterampilan berbicara melalui teknik bercerita dan berpidata mahasiswa Program Studi Pendidikan Bahasa Indonesia FKIP Universitas Bengkulu penting dilakukan melalui penelitian tindakan kelas.

\section{B. Metode Penelitian}

Metode penelitian menggunakan metode Penelitian Tindakan Kelas (PTK) dengan model Hopkins. Arikunto dkk. (2012:9) mendeskripsikan PTK 
dilaksanakan dalam siklus yang terdiri atas empat tahapan, yakni (1) tahap perencanaan (planning), (2) tahap pelaksanaan (acting), (3) tahap pengamatan (observing), dan (4) tahap refleksi (reflecting). Sebagaimana dikemukakan juga oleh Hopkins (Sanjaya, 2013:53) yang mendeskripsikan tiap siklus PTK atas empat tahapan yakni perencanaan, pelaksanaa, pengamatan, dan refleksi. Penelitian Tindakan Kelas ini dilaksanakan dalam dua siklus. Kegiatan siklus I dilaksanakan pada tanggal 14 dan 16 Mei 2018 serta kegiatan tes penampilan bercerita dan berpidato dilaksanakan pada tanggal 18 Mei 2018. Hasil refleksi siklus I dilanjutkan dengan pembelajaran siklus II pada tanggal 21 dan 23 Mei 2018 serta kegiatan tes penampilan pada tanggal 25 Mei 2018.

Data penelitian berupa kecakapan tampilan mahasiswa dalam bercerita dengan tema 'kasih sayang' dan berpidato dengan tema 'integritas bangsa' dari mahasiswa semester II kelas A sebanyak 34 orang yang ditetapkan melalui teknik bertujuan (purposive sampling). Teknik pengumpulan data dilakukan menggunakan teknik tes penampilan dalam bercerita dan berpidato dengan menggunakan alat pengumpul data berupa rubrik penilaian keterampilan bercerita dan berpidato mahasiswa yang mencakup sembilan aspek dengan dengan bobot berbeda-beda dan skor maksimal 100. Instrumen pengamatan aktivitas mahasiswa dalam perkuliahan didasarkan pada lima karakter yakni integritas, kemandirian, disiplin, kejujuran, dan tanggung jawab serta mengumpul tugas tepat waktu.

Analisis data utama menggunakan statistik deskriptif dengan rumus rerata dan persentase dan hasil akhirnya dikonfirmasi secara kualitatif. Indikator keberhasilan kegiatan pembelajaran keterampilan berbicara dengan teknik bercerita dan berpidato ini dinyatakan berhasil apabila mahasiswa secara individual mendapat skor minimal 75 dan secara klasikal jika sebanyak $80 \%$ mahasiswa mendapatkan rerata skor 75. Hasil tersebut perlu diikuti dengan aktivitas mahasiswa dalam perkuliahan yang minimal berkategori aktif. 


\section{Hasil Penelitian dan Pembahasan}

\section{Hasil Penelitian}

a. Pembelajaran Siklus I

Hasil penelitian siklus I dilakukan dalam empat tahapan yakni: (a) tahap Perencanaan, mendeskripsikan persiapan rancangan pembelajaran, skenario pembelajaran, perangkat pengamatan, dan perangkat penilaian keterampilan berbicara dengan teknik bercerita dan berpidato, (b) tahap pelaksanaan pembelajaran mencakup pendahuluan, inti, dan penutup yang dilanjutkan dengan tes penampilan bercerita dan berpidato, (c) tahap pengamatan berkaitan dengan deskripsi aktivitas mahasiswa dalam perkuliahan, dan (d) tahap refeksi yang mengemukakan hal yang sudah dilakukan dan yang belum dilakukan atau yang perlu dilakukan lebih lanjut.

Berdasarkan data siklus I hasil tes praktik penampilan bercerita dan berpidato, bahwa keterampilan berbicara mencapai skor rerata sebesar 71,88 berkategori baik. Hal ini menunjukkan bahwa keterampilan berbicara mahasiswa masih memerlukan upaya peningkatan dalam proses dan hasil pembelajarannya. Hal ini dapat dilihat dari (1) teknik bercerita mahasiswa berkategori baik dengan rerata skor sebesar 72,9 dan (2) teknik berpidato juga berkategori baik dengan rerata skor sebesar 70,85. Dari sembilan aspek yang dinilai pada kedua teknik (bercerita dan berpidato) dalam keterampilan berbicara mahasiswa semua memperoleh kategori baik. Hasil ini belum mencapai indikator keberhasilan yang dipersyaratkan. Adapun capaian sesuai frekuensi dari kedua teknik (bercerita dan berpidato) sebagaimana tabel berikut.

Tabel 1. Frekuensi dan Kategori Capaian Keterampilan Berbicara dengan Teknik Bercerita dan Berpidato Mahasiswa Pada Siklus I

\begin{tabular}{clccccc}
\hline \multirow{2}{*}{ No. } & \multirow{2}{*}{ Kategori } & \multicolumn{2}{c}{ Bercerita } & \multicolumn{2}{c}{ Berpidato } & \multirow{2}{*}{ Rerata (\%) } \\
\cline { 3 - 6 } & & $\mathbf{F}$ & $\mathbf{\%}$ & $\mathbf{F}$ & $\mathbf{\%}$ & \\
\hline 1 & Sangat Baik & 0 & 0 & 0 & 0 & 0 \\
\hline 2 & Baik & 32 & 94,12 & 30 & 88,24 & 91,18 \\
\hline 3 & Cukup & 2 & 5,88 & 4 & 11,76 & 8,82 \\
\hline 4 & Kurang & 0 & 0 & 0 & 0 & 0 \\
\hline 5 & Sangat Kurang & 0 & 0 & 0 & 0 & 0 \\
\hline & Total & 34 & 100 & 34 & 100 & 100 \\
\hline
\end{tabular}


Data capaian frekuensi mahasiswa di atas menunjukkan bahwa keterampilan berbicara mahasiswa baik yang menggunakan teknik bercerita maupun teknik berpidato masih berada pada capaian yang sama, yakni pada kategori baik dan ketegori cukup. Hasil ini menunjukkan bahwa secara individual sudah berhasil tetapi secara klasikal berdasarkan rerata aspek yang dinilai belum berhasil atau belum mencapai hasil maksimal. Dari frekuensi tiap aspek di atas dapat digambarkan pada diagram batang berikut ini.

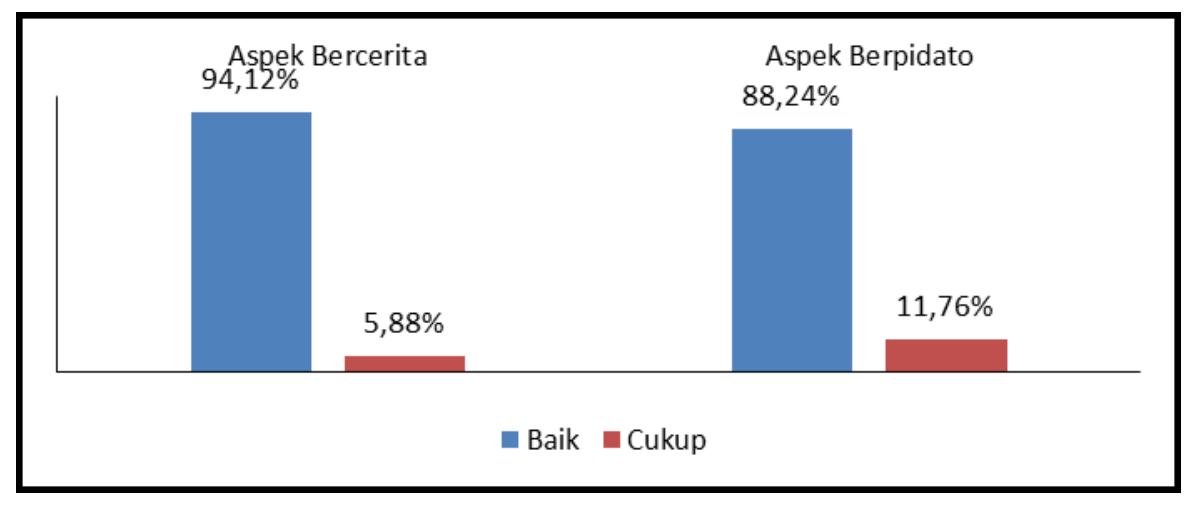

Diagram 1. Persentase Frekuensi Pencapaian Keterampilan Berbicara dengan Teknik Bercerita dan Berpidato Mahasiswa Siklus I

Hasil tes keterampilan berbicara di atas diiringi dengan hasil pengamatan aktivitas mahasiswa dalam mengikuti perkuliahan mencakup sikap integritas, disiplin, tanggung jawab, kemandirian, dan kejujuran yang secara umum berkategori aktif. Berdasarkan besarnya sikap yang menyatakan aktivitas secara khusus bahwa sebanyak $88,2 \%$ sudah bersikap aktif. Hal ini sebagaimana tabel berikut.

Tabel 2. Persentase Aktivitas Proses Pembelajaran Keterampilan Berbicara Mahasiswa Berdasarkan Besaran Sumbangan Setiap Aspeknya pada Siklus I

\begin{tabular}{|c|c|c|c|c|}
\hline \multirow{2}{*}{ No. } & \multirow{2}{*}{ ASPEK } & \multicolumn{2}{|c|}{ Aktivitas Mhs } & \multirow{2}{*}{$\begin{array}{c}\text { BS-A } \\
\text { (\%) }\end{array}$} \\
\hline & & F-A & $\%$ & \\
\hline 1 & Integritas & 27 & 79,4 & 18 \\
\hline 2 & Disiplin & 33 & 97,1 & 22 \\
\hline 3 & Kemandirian & 30 & 88,2 & 20 \\
\hline 4 & Tanggung Jawab & 28 & 82,4 & 18,7 \\
\hline \multirow[t]{3}{*}{5} & Kejujuran & 32 & 94,1 & 21,3 \\
\hline & Total & 150 & 441,2 & 100 \\
\hline & Rerata & 30 & 88,2 & \\
\hline
\end{tabular}

Silampari Bisa: Jurnal Penelitian Pendidikan Bahasa Indonesia, Daerah, dan Asing Vol. 3, No. 2, 2020 
Frekuensi aktivitas mahasiswa dalam proses pembelajaran keterampilan berbicara yang berkategori Aktif mencapai rerata $88,2 \%$ yang mencakup (1) integritas sebanyak 27 orang, (2) disiplin sebanyak 33 orang, (3) kemandirian sebanyak 30 orang, (4) tanggung jawab sebanyak 28 orang, dan (5) kejujuran sebanyak 32 orang dari pemilih tiap aspek sebanyak 34 orang. Aspek pemilih terbanyak diberikan pada aspek disiplin yang diikuti aspek kejujuran. Persentase besarnya sumbangan setiap aspek itu menunjukkan bahwa mahasiswa sudah berkategori Aktif tetapi karena selebihnya masih cukup maka masih perlu perbaikan. Deskripsi setiap aspek dapat dilihat pada diagram batang berikut ini.

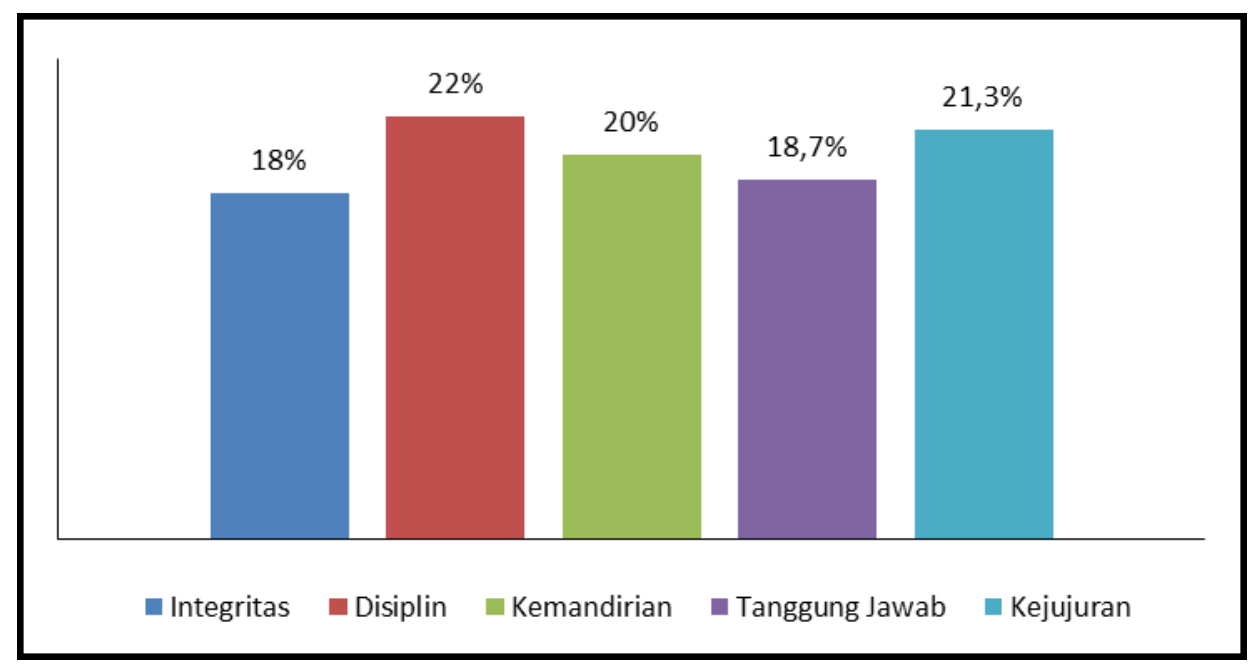

Diagram 2. Pencapaian Kategori Aktif Pembelajaran Keterampilan Berbicara Mahasiswa Berdasarkan Persentase Sumbangan Setiap Aspeknya pada Siklus I

Deskripsi Pencapaian aktivitas pembelajaran keterampilan berbicara mahasiswa yang menggunakan teknik bercerita dan berpidato pada siklus I secara umum berkategori aktif. Hal ini didasarkan pada besar sumbangan dari lima aspek aktivitas mencakup, yakni (1) integritas memberi sumbangan sebesar $18 \%$, (2) disiplin memberi sumbangan sebesar $22 \%$, (3) kemandirian memberi sumbangan sebesar $20 \%$, (4) tanggung jawab memberi sumbangan sebesar $18,7 \%$, dan (5) kejujuran memberi sumbangan sebesar $21,3 \%$. Sumbangan tertinggi diberikan aspek disiplin dan diikuti aspek kejujuran.

Berdasarkan perencanaan, hasil tes penampilan, dan aktivitas dalam pembelajaran keterampilan berbicara mahasiswa, bahwa (1) keterampilan 
berbicara dengan teknik bercerita dan berpidato pada siklus I ini telah berjalan dengan baik dan mencapai kategori baik. Hal ini telah diiringi dengan aktivitas mahasiswa proses pembelajaran yang juga dideskripsikan berkategori aktif secara individual. Namun, secara klasikal belum mencapai indikator keberhasilan. Oleh karena itu, proses pembelajaran keterampilan berbicara perlu dilanjutkan pada siklus II untuk mencapai hasil sesuai dengan indikator keberhasilan.

\section{b. Pembelajaran Siklus II}

Hasil penelitian siklus I jugal dilakukan dalam empat tahapan yakni (a) tahap Perencanaan, memperbaiki persiapaan rancangan mengajar, skenario pembelajaran, pedoman pengamatan, dan pedoman penilaian keterampilan berbicara dengan kedua teknik yang diterapkan lebih baik, (b) tahap pelaksanaan mencakup pendahuluan, inti, dan penutup yang dilanjutkan dengan tes penampilan praktik berbicara dan berpidato, (c) tahap pengamatan berkaitan dengan aktivitas mahasiswa dalam perkuliahan, dan (d) tahap refeksi yang mengemukakan hal yang sudah dilakukan dan yang perlu dilakukan lebih lanjut.

Berdasarkan data siklus II hasil tes praktik penampilan bercerita dan berpidato, bahwa keterampilan berbicara mencapai skor rerata sebesar 81,18 berkategori sangat baik. Hal ini menunjukkan bahwa keterampilan berbicara mahasiswa sudah mencapai kualitas maksimal. Hal ini dapat dilihat dari (1) teknik bercerita mahasiswa berkategori sangat baik dengan skor 80,7 dan (2) teknik berpidato juga berkategori sangat baik dengan skor 81,65. Dari sembilan aspek yang dinilai dalam keterampilan berbicara mahasiswa semua memperoleh kategori sangat baik atau secara individual sudah mencapai indikator keberhasilan. Adapun capaian sesuai frekuensi dari kedua teknik (bercerita dan berpidato) sebagaimana tabel berikut. 
Tabel 3. Persentase Frekuensi dan Kategori Keterampilan Berbicara Mahasiswa Berdasarkan Teknik Bercerita dan Berpidato Siklus II

\begin{tabular}{|c|c|c|c|c|c|c|}
\hline \multirow{2}{*}{ No. } & \multirow{2}{*}{ Kategori } & \multicolumn{2}{|c|}{ Bercerita } & \multicolumn{2}{|c|}{ Berpidato } & \multirow{2}{*}{$\begin{array}{c}\text { Rerata } \\
(\%)\end{array}$} \\
\hline & & Frekuensi & Persentase & Frekuensi & Persentase & \\
\hline 1 & Sangat Baik & 23 & 67,6 & 28 & 82,4 & 75 \\
\hline 2 & Baik & 11 & 32,4 & 6 & 17,6 & 25 \\
\hline 3 & Cukup & 0 & 0 & 0 & 0 & 0 \\
\hline 4 & Kurang & 0 & 0 & 0 & 0 & 0 \\
\hline \multirow[t]{2}{*}{5} & Sangat Kurang & 0 & 0 & 0 & 0 & 0 \\
\hline & Total & 34 & 100 & 43 & 100 & 100 \\
\hline
\end{tabular}

Dari tabel frekuensi di atas dapat dikemukakan bahwa keterampilan berbicara mahasiswa yang menggunakan teknik bercerita dan teknik berpidato berada pada capaian yang sama, yakni pada kategori sangat baik (75\%) dan pada ketegori baik (25\%). Capain kemampuan berbicara secara individual dan klasikal dari aspek bercerita bahwa sebanyak 23 orang $(67,6 \%)$ sudah berkategori sangat baik dan 11 orang (32,4\%) berkategori baik sedangkan dari aspek berpidato bahwa sebanyak 28 orang $(82,4 \%)$ berkategori sangat baik dan 6 orang $(17,6 \%)$ berkategori baik. Hasil ini menunjukkan bahwa keterampilan berbicara mahasiswa sudah mencapai hasil maksimal. Data tersebut digambarkan pada diagram batang berikut ini.

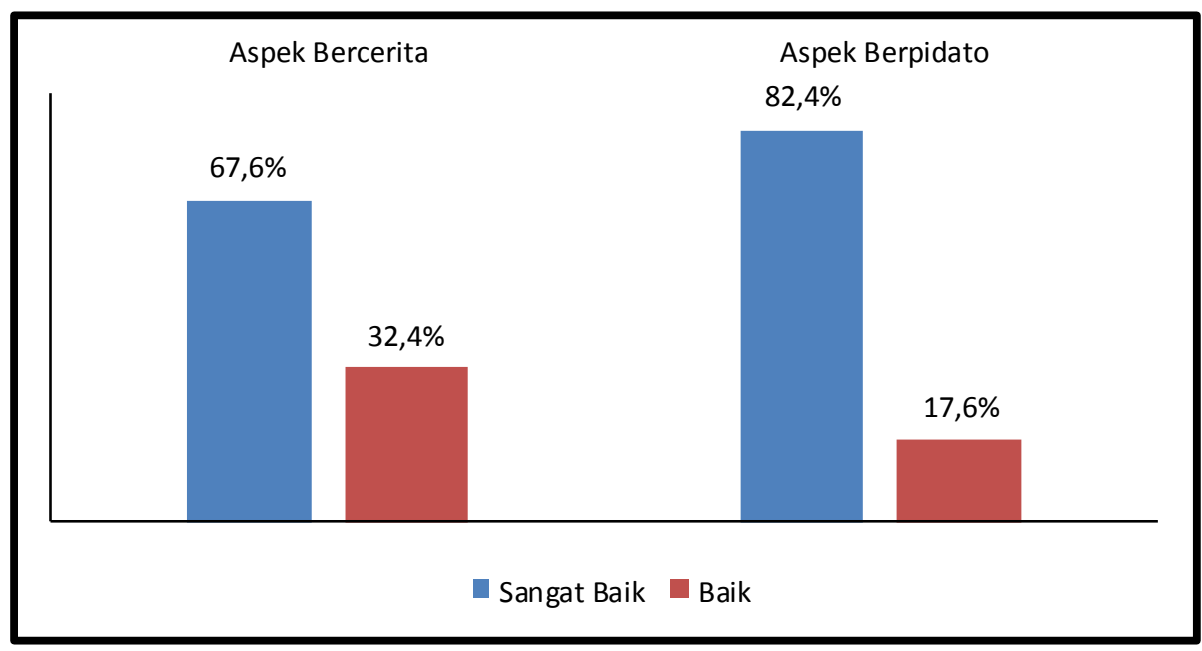

Diagram 3. Pencapaian Persentase Frekuensi Keterampilan Berbicara Mahasiswa Berdasarkan Aspek Bercerita dan Berpidato Siklus II

Deskripsi capaian pada diagram di atas menunjukkan bahwa keterampilan berbicara yang menggunakan teknik bercerita dan berpidato sudah dikuasai mahasiswa walaupun belum semua mencapai skor maksimal. 
Hasil tes keterampilan berbicara di atas sudah diikuti dengan hasil pengamatan aktivitas mahasiswa dalam mengikuti perkuliahan mencakup sikap integritas, disiplin, tanggung jawab, kemandirian, dan kejujuran yang secara umum berkategori sangat aktif. Berdasarkan besarnya sikap yang menyatakan aktivitas secara khusus bahwa sebanyak $82,94 \%$ sudah bersikap sangat aktif. Hal ini sebagaimana tabel berikut

Tabel 4. Persentase Aktivitas Proses Pembelajaran Keterampilan Berbicara Mahasiswa Berdasarkan Besaran Sumbangan Setiap Aspeknya Pada Siklus II

\begin{tabular}{|c|c|c|c|c|c|c|c|}
\hline \multirow{2}{*}{ No. } & \multirow{2}{*}{ ASPEK } & \multicolumn{2}{|c|}{ Aktivitas Mhs } & \multirow{2}{*}{$\begin{array}{c}B S-S A \\
(\%)\end{array}$} & \multicolumn{2}{|c|}{ Aktivitas Mhs } & \multirow{2}{*}{$\begin{array}{c}B S-A \\
(\%)\end{array}$} \\
\hline & & F-SA & $\%$ & & $F-A$ & $\%$ & \\
\hline 1 & Integritas & 30 & 88,2 & 21,3 & 4 & 11,8 & 13,8 \\
\hline 2 & Disiplin & 25 & 73,5 & 17,7 & 9 & 26,5 & 31,1 \\
\hline 3 & Kemandirian & 32 & 94,1 & 22,7 & 2 & 5,9 & 6,9 \\
\hline 4 & Tanggung Jawab & 26 & 76,5 & 18,4 & 8 & 23,5 & 27,6 \\
\hline 5 & Kejujuran & 28 & 82,4 & 19,9 & 6 & 17,6 & 20,6 \\
\hline & Total & 141 & 414,7 & 100 & 29 & 85,3 & 100 \\
\hline & Rerata & 28,2 & 82,94 & & 5,8 & 17,06 & \\
\hline
\end{tabular}

Pada tabel di atas dapat dikemukakan bahwa frekuensi aktivitas mahasiswa dalam proses pembelajaran keterampilan berbicara yang berkategori Sangat Aktif mencakup (1) integritas sebanyak 30 orang, (2) disiplin sebanyak 25 orang, (3) kemandirian sebanyak 32 orang, (4) tanggung jawab sebanyak 26 orang, dan (5) kejujuran sebanyak 28 orang atau secara keseluruhan mencapai total 141 pemilih dari semua aspek sebanyak 34 orang, yang selebihnya adalah kategori aktif (total pemilih sebanyak 29). Artinya, aktivitas mahasiswa secara klasikal telah melebihi $80 \%$ batas minimal indikator keberhasilan, yakni $82,94 \%$ kategori sangat aktif dan 17,06\% kategori aktif dan secara individual telah tercapai dengan rerata skor 81,18 kategori sangat baik. Persentase besaran sumbangan setiap aspek aktivitas mahasiswa kategori Sangat Aktif dapat dilihat pada diagram batang berikut ini. 


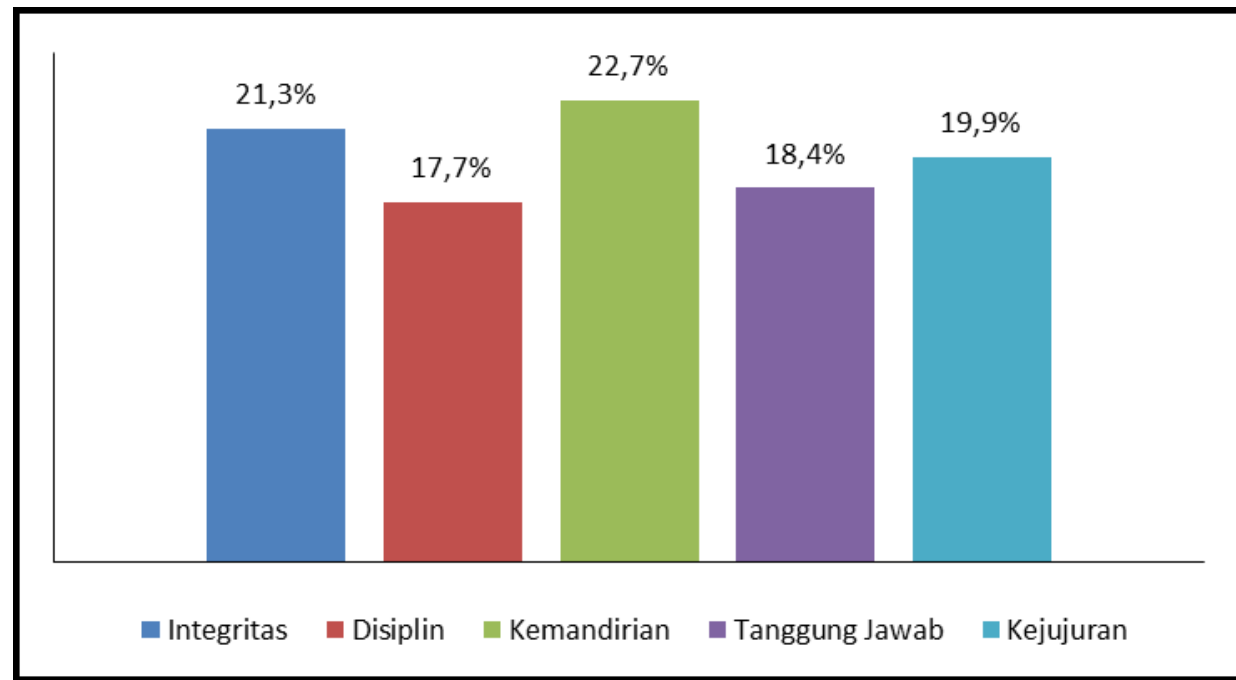

Diagram 4. Pencapaian Kategori Sangat Aktif Keterampilan Berbicara Mahasiswa Berdasarkan Persentase Sumbangan Setiap Aspeknya Pada Siklus II

Deskripsi Pencapaian aktivitas pembelajaran keterampilan berbicara mahasiswa yang menggunakan teknik bercerita dan berpidato pada siklus II secara umum berkategori Sangat Aktif. Hal ini didasarkan pada besar sumbangan lima aspek aktivitas mahasiswa mencakup, yakni (1) integritas memberi sumbangan sebesar 21,3\%, (2) disiplin memberi sumbangan sebesar 17,7\%, (3) kemandirian memberi sumbangan sebesar 22,7\%, (4) tanggung jawab memberi sumbangan sebesar 18,4\%, dan (5) kejujuran memberi sumbangan sebesar $19,9 \%$. Sumbangan tertinggi diperoleh dari aspek kemandirian.

Secara keseluruhan, proses dan hasil pembelajaran keterampilan berbicara mahasiswa pada siklus II dapat direfleksikan bahwa (1) hasil pembelajaran keterampilan berbicara yang menggunakan teknik bercerita dan berpidato telah berjalan dengan baik dan mencapai kategori sangat baik dan (2) hasil tersebut telah diikuti dengan aktivitas proses pembelajaran mahasiswa yang juga dideskripsikan berkategori sangat aktif atau secara individual dan klasikal dan telah mencapai indikator keberhasilan. Artinya, sudah terjadi peningkatan keterampilan berbicara yang menggunakan teknik bercerita dan berpidato sehingga tidak perlu dilanjutkan pada siklus berikutnya. 


\section{Pembahasan}

Penggunaan teknik bercerita dan berpidato telah meningkatkan hasil keterampilan berbicara yang diikuti dengan proses pembelajaran mahasiswa yang juga meningkat. Hal ini berarti bahwa teknik bercerita dan berpidato yang dilakukan telah mampu memberikan perubahan sikap mahasiswa khususnya pada aspek integritas, kemandirian, disiplin, tanggung jawab, dan kejujuran dalam mengikuti perkuliahan. Peningkatan hasil keterampilan berbicara dari 34 orang mahasiswa ini terjadi dalam dua siklus proses pembelajaran. Pada siklus I hasil pembelajaran keterampilan berbicara mencapai rerata skor sebesar 71,88 berkategori baik mengalami peningkatan pada siklus II dengan rerata skor sebesar 81,18 berkategori sangat baik. Secara spesifik bahwa pada hasil pembelajaran siklus I keterampilan berbicara yang menggunakan teknik bercerita berkategori baik dengan rerata skor sebesar 72,9 dan yang menggunakan teknik berpidato juga berkategori baik dengan rerata skor sebesar 70,85 mengalami peningkatan pada hasil pembelajaran siklus II keterampilan berbicara yang menggunakan teknik bercerita berkategori sangat baik dengan rerata skor sebesar 80,7 dan yang menggunakan teknik berpidato berkategori sangat baik dengan rerata skor sebesar 81,65.

Peningkatan keterampilan berbicara dengan teknik bercerita dan berpidato ini juga diiringi dengan meningkatnya aktivitas proses pembelajaran mahasiswa dalam kelima aspek integritas, kemandirian, disiplin, tanggung jawab, dan kejujuran dari kualifikasi aktif pada siklus I meningkat menjadi sangat aktif pada siklus II. Peningkatan ini sesuai dengan pendapat Rivers (dalam Hadley, 1993) bahwa keterampilan berbicara sebagai kecakapan seseorang dalam praktik berbahasa lisan harus tercermin dari perubahan dalam hal penuangan pikiran dalam pengembangan ide atau gagasan untuk mewujudkan isi pembicaraan, ketepatan pilihan kata, pengunaan kalimat dan paragraf yang runtut, jelas, dan lengkap baik dalam bercerita maupun dalam berpidato yang dapat dipahami oleh pendengarnya. 
Secara khusus bahwa hasil keterampilan berbicara dengan teknik bercerita dan berpidato dinilai dengan menggunakan rubrik penilaian praktik lisan yang melibatkan sembilan aspek mencakup (1) kesesuaian topik atau tema dengan isi bercerita dan berpidato, (2) ketepatan lafal, intonasi, dan jeda, (3) kesesuaian struktur teks tulis cerita dan pidato, (4) ketepatan pengembangan diksi, kalimat, dan paragraf, (5) ketepatan gaya pengucapan, (6) kelancaran dalam bercerita dan berpidato, (7) kepercayaan diri dan keberanian, (8) kesesuaian pengembangan wawasan dalam bercerita dan berpidato, dan (9) penampilan yang mencakup pandangan mata, mimik, gerakan tubuh, dan cara berpakaian. Pada siklus 1 walaupun pada semua aspek berkategori baik tetapi aspek kesesuaian tema dengan isi khususnya pada teknik bercerita telah dikuasai mahasiswa dalam menyampaikan isi cerita secara lebih baik. Hal ini tergambar dari cara menguraikan isi dalam bercerita. Kepiawaian mahasiswa menguraikan isi dalam bercerita ini relevan dengan cara menuliskan urutan struktur teks cerita yang sudah tepat. Ketepatan struktur ini juga terjadi pada teks pidato.

Dari segi nonkebahasaan mahasiswa juga sudah mampu mengembangkan lebih baik dari aspek lainnya temasuk cara berimprofisasi dalam penampilan praktik khususnya ketika menghayati isi cerita atau pidato sehingga tampilan mimik, gerakan yang didukung cara berpakaian sudah sesuai dengan isi cerita atau pesan pidato yang disampaikan. Pada siklus II semua aspek mengalami peningkatan penguasaan khususnya perubahan pada cara melafalkan, intonasi, dan jeda ketika bercerita dan berpidato menjadi lebih baik yang masih relevan dengan ketepatan struktur teks yang ditulis dan disajikan dalam penampilan. Peningkatan aspek gaya pengucapan, kelancaran, dan kepercayaan diri juga terjadi pada tampilan berpidato yang diikuti secara baik penampilan mimik, gerakan tubuh dalam bercerita dan berpidato (Noermanzah dkk., 2019).

Hasil praktik pembelajaran pada siklus I berkategori baik dengan rerata skor sebesar 71,88 atau secara spesifik aspek bercerita dengan skor 72,9 berkategori baik dan aspek berpidato dengan skor 70, 9 berkategori baik mengalami peningkatan pada siklus II berkategori sangat baik dengan rerata skor sebesar 81,18 atau secara spesifik aspek bercerita berkategori sangat baik 
dengan rerata skor sebesar 80,7 dan aspek berpidato juga mencapai kategori sangat baik dengan rerata skor sebesar 81,65. Hal ini sudah sangat sesuai sebagaimana dikemukakan Ross dan Roe (dalam Rofi'udin dan Zuhdi, 2001:13) bahwa hal tersebut (bercerita dan berpidato) penting dilakukan dalam upaya meningkatkan keterampilan berbicara seseorang khususnya dalam mendapatkan informasi secara lisan yang memerlukan penguasaan unsur kebahasaan dan nonkebahasan seperti penampilannya yang melibatkan cara berbicara, cara berpakaian, cara memandang, dan bahkan cara melangkah atau gerak-gerik anggota tubuh. Dalam hal praktik berbicara ini masih belum sempurna. Artinya, khusus faktor penampilan berbicara mahasiswa perlu terus diperbaiki dan dilatihkan agar menghasilkan model tampilan yang maksimal.

Disisi lain, bahwa capaian keterampilan berbicara yang meningkat secara lebih baik pada hasil pembelajaran keterampilan berbicara dengan teknik bercerita dan berpidato juga diikuti dengan meningkatannya aktivitas belajar mahasiswa dari kategori aktif dari unsur (1) integritas, (2) kemandirian, (3) disiplin, (4) tanggung jawab, dan (5) kejujuran pada siklus I dan meningkat menjadi berkategori sangat aktif pada siklus II. Hal ini berarti bahwa proses pembelajaran yang melibatkan aktivitas mahasiswa juga diikuti dengan hasil pembelajaran keterampilan berbicara secara lebih baik dan bahkan maksimal. Hasil praktik pembelajaran yang tidak dapat dipisahkan dari aktivitas proses pembelajaran mahasiswa ini berorientasi individual atau kemandirian. Artinya, aktivitas dalam perkuliahan atau proses pembelajaran yang lebih baik dapat terjadi karena mahasiswa mengikuti aturan. Dalam hal disiplin misalnya akan mendapatkan nilai baik apabila hadir tepat waktu, sebelum proses pembelajaran dimulai sudah di ruangan, tanggung jawab akan berkategori baik apabila tugas diselesaikan sesuai ketentuan, dan kemandirian akan baik apabila setelah bekerja bersama-sama teman lain dia dapat mewujudkan tugas individunya seperti menulis teks cerita dan teks pidato serta aspek integritas dan kejujuran akan berhasil dicapai siswa bila menunjukkan sikap yang berorientasi pada keyakinan semangat melakukan untuk keberhasilan, percaya kepada Sang Pencipta pada setiap perilakunya. Pada 
aspek kejujuran menunjukkan dan berkata jujur ketika mengatakan sesuatu yang memang harus diucapkan yang sebenarnya.

Pada lafal bahasa Indonesia, ketepatan lafal akan tampak ketika tampil praktik berbicara. Masih terdapat lafal yang sering mengganggu dan salah dalam berbicara seperti ketika melafalkan kata 'rumah' menjadi 'ruma', 'bisa' justru menjadi 'bisah', tetapi ketika melafalkan kata "sudah" malahan menjadi "sudah". Hal ini terjadi karena pengaruh bahasa ibu atau bahasa daerah. Ketidaktepatan lafal juga terjadi pada kata serapan dari bahasa Inggris seperti kata "film" dilafalkan "filem", atau "pilem." Pada aspek percaya diri masih tampak beberapa mahasiswa yang belum memiliki keberanian dalam mengungkapkan ide atau gagasan, seperti ketika menjelaskan suatu konsep belum lengkap karena belum mempelajari secara benar buku teori yang harus dibaca termasuk masih ada mahasiswa yang "grogi" ketika tampil di depan teman-temannya untuk dinilai. Beberapa hal yang belum menunjukkan capaian yang baik ini perlu dilakukan perbaikan melalui latihan dan praktik yang rutin dan terus-menerus sehingga menghasilkan penampilan yang maksimal.

Perubahan pada aktivitas proses pembelajaran mahasiwa sangat penting karena merupakan proses yang akan berdampak pada hasil pembelajaran menjadi lebih baik atau maksimal. Perubahan aktivitas mahasiswa misalnya terjadi pada siklus I dari besar sumbangan aspek kemandiri sebesar $20 \%$ meningkat pada siklus II dengan besar sumbangan kemandirian sebesar 25\%. Hal ini menunjukkan bahwa secara individual terjadi perubahan proses pembelajaran dan diikuti dengan hasil pembelajaran yang lebih baik atau sebaliknya.

\section{Simpulan dan Saran}

Berdasarkan hasil penelitian dan pembahasan dapat disimpulkan bahwa telah terjadi peningkatan dalam proses dan hasil pembelajaran keterampilan berbicara yang menggunakan teknik bercerita dan teknik berpidato mahasiswa Program Studi S-1 Pendidikan Bahasa Indonesia FKIP Universitas Bengkulu. Hal ini dapat dilihat dari hasil pembelajaran siklus I yang berkategori baik dengan rerata skor sebesar 71,88 meningkat pada siklus II berkategori sangat baik 
dengan rerata skor sebesar 81,18. Hasil tersebut diikuti dengan perubahan aktivitas belajar mahasiswa proses pembelajaran yang melibatkan aspek sikap integritas, kemandirian, disiplin, tanggung jawab, dan kejujuran pada siklus I dengan kategori aktif menjadi sangat aktif pada siklus II. Artinya, proses pembelajaran dapat diikuti oleh mahasiswa sehingga mampu mengubah secara lebih baik proses dan hasil pembelajarannya.

Berdasarkan pada simpulan di atas, saran untuk peningkatan secara lebih baik khususnya pada mahasiswa yakni perlu lebih banyak melatih diri dalam kegiatan praktik penampilan dalam keterampilan berbicara khususnya dalam praktik bercerita dan berpidato yang dibarengi dengan keterampilan dalam menulis teks cerita dan teks pidato.

\section{E. Ucapan Terima Kasih}

Peneliti mengucapkan terima kasih kepada pimpinan FKIP Universitas Bengkulu yang telah mendanai melalui RBA 2018 dan LPPM Universitas Bengkulu yang telah memfasilitasi perizinan persiapan proposal dan proses pelaksanaan kegiatan ini hingga selesai.

\section{Daftar Pustaka}

Arikunto, S., Suhardjono, dan Supardi. (2012). Penelitian Tindakan Kelas. Jakarta: PT. Bumi Aksara.

Bachman, L. F. (1990). Fundamental Considerations in Language Testing. Oxford: Oxford University Press.

Djiwandono, S. (2008). Tes Bahasa Pegangan Bagi Pengajar Bahasa. Jakarta: PT Indeks.

Hadley, A. O. (1993). Teaching Language in Context. Boston: Heinle \& Heinle Publishers.

Haryadi dan Zamzami. (1996). Peningkatan Keterampilan Berbahasa Indonesia. Jakarta: Departemen Pendidikan dan Kebudayaan RI.

Haswindy, S. (2020). Peningkatan Kompetensi Profesional dan Pedagogik Guru SMA di Provinsi Jambi. Jurnal Khazanah Intelektual, 2(2), 203. doi:10.37250/newkiki.v2i2.25 
Hisam. (2016). Bercerita: 10 Pengertian Menurut Para Ahli dan (Jenis-ManfaatTujuan). http;www. dosenpendidikan.com. Diunduh 5 Mei 2020.

Jazeri, M. (2016). Model Perangkat Pembelajaran Keterampilan Berbicara dengan Pendekatan Komunikatif Kontekstual bagi Mahasiswa Asing. LITERA, 15(2), 218. doi:10.21831/ltr.v15i2.11824

Kemdikbud. (2013). Bahasa Indonesia: Wahana Pengetahuan untuk SMP/MTs Kelas VII. Buku Siswa. Jakarta: Kementerian Pendidikan dan Kebudayaan.

Mudini dan Purba, S. (2009). Pembelajaran Berbicara. Jakarta: Ditjen PMP dan TK P4TK Bahasa, Depdiknas.

Noermanzah, Emzir, \& Lustyantie, N. (2018). President Joko Widodo's Rhetorical Technique of Arguing in the Presidential Speeches of the Reform Era. International Journal of Applied Linguistics and English Literature, 7(5), 119120. doi: $10.7575 / a i a c . i j a l e l . v .7 n .5 p .117$

Noermanzah, Wardhana, D. E. C., Friantary, H., Arsyad, S. (2019). Joko Widodo's Rhetorical Structure in the Presidential Speeches for Addressing Educational Problems. International Journal of Scientific and Technology Research, 8(10). 1794-1795, http://www.ijstr.org/paper-references.php?ref=IJSTR-1019-22878

Nurgiyantoro, B. (2001). Penilaian dalam Pengajaran Bahasa dan Sastra Edisi ke-3. Yogyakarta: PT BPFE.

OECD. (2014). PISA 2012 Results: What Students Know and Can Do (Student Performance in Mathematics, Reading and Sciences). Paris: OECD Publications.

Rofi'udin, A. dan Zuchdi, D. (2001). Pendidikan Bahasa dan Sastra Indonesia Kelas Tinggi. Malang: Universitas Negeri Malang.

Sanjaya, W. (2013). Penelitian Tindakan Kelas. Jakarta: Kencana Prenadamedia Group.

Satori. (2013). "Komponen Kompetensi Profesional Guru”, Pendidikanku: Informasi Pendidikan Terkini. Http://sdnwonoue.blogspot.com/2013/08.html. Diunduh, 27 April 2020.

Tarigan, D., dkk. (1983). Teknik Pengajaran Keterampilan Berbahasa. Bandung: Angkasa.

Tarigan, D., dkk. (2008). Pengembangan Keterampilan Berbicara. Jakarta: Depdikbud.

Tarigan, H. G. (1981). Berbicara Sebagai Suatu Keterampilan Berbahasa. Bandung: Angkasa. 